\title{
ANALYSIS OF CREDIT INSTITUTIONS' RISKS IN THE BANCASSURANCE MARKET
}

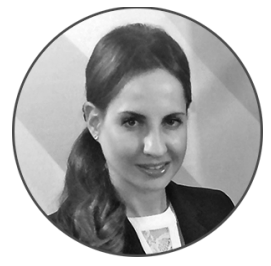

\author{
Ol'ga A. YUSUPOVA \\ Russian University of Transport, Moscow, Russian Federation \\ qwerty6020@mail.ru \\ https://orcid.org/0000-0002-0836-6866
}

\begin{abstract}
Article history:
Received 9 July 2018

Received in revised form

25 July 2018

Accepted 9 August 2018

Translated 22 January 2019

Available online 29 March 2019

JEL classification: $\mathrm{G} 21, \mathrm{G} 23, \mathrm{G} 32$

Keywords: banking risk, bank exposure, collective agreements to agency. The unregulated nature of this aspect may cause massive bankruptcy of insurance bank insurance, bancassurance, sales channel

Abstract

Subject The intensifying competition in the financial market urged its residents to create complex products, establish partnership relations and cross-distribution channels. Bancassurance became a new area of cooperation. The business cooperation of banks and insurance companies not only presents new product offerings for customers and enable them to increment their income, but also entails various risks.

Objectives The research studies the premises and nature of banking risks in the bancassurance segment, defines its types, evaluates consequences and outlines preventative measures.

Methods Studying banking risks, I applied methods of logic and economic analysis.

Results I examined the current situation in the bancassurance segment, determined its key trends, pinpointed banking risk factors and proposed the typification of risks detailed as per credit and non-credit insurance. Based on the typification, I conducted the comprehensive analysis of each type of probable scenarios.

Conclusions and Relevance The probability and level of the bancassurance risk depend on the type of an insurance product, status of the bank acting as a beneficiary or agent, bank's affiliation with the insurance company, quality and performance of insurer certification requirements the banks sets. Banking is exposed to serious reputation risks. The opaque partner acceptance system triggers abuses during the transition from companies, undermine the public confidence and corporate customers in financial institutions and damage the megaregulator's reputation.
\end{abstract}

The editor-in-charge of this article was Irina M. Vechkanova Authorized translation by Irina M. Vechkanova

\section{Introduction}

Discussions. As the contemporary market poses new challenges, today's banking product offerings are much more than a static array of conditions and parameters banks are ready to provide, but rather rapidly adjustable and complex mechanism, which is driven smoothly and effectively by all departments of a bank.

The translational motion of the mechanism depends on multiple related processes pursuing the same goals and

${ }^{\dagger}$ For the source article, please refer to: Юсупова О.А. Анализ рисков кредитных организаций на рынке банкострахования // Финансы и кредит. 2018. Т. 24. № 11. С. 2486-2502.

URL: https://doi.org/10.24891/fc.24.11.2486 target and being entwined with its through the integration and cooperation of commercial banks with other market actors, i.e. suppliers of goods and services, payment systems and insurance companies.

Such cooperation engenders comprehensive hybrid products in the market (credit cards and installment cards as their derivative option, which offer various bonuses, grace periods, cashback, insurance products that are provided for loans, credit cards and ownership, etc.). CRM systems get more complicated year on year, with cross-selling channels growing steadily.

The advantage of such synergy is obvious. Credit institutions expand their clientele offering a compound

Please cite this article as: Yusupova 0.A. Analysis of Credit Institutions' Risks in the Bancassurance Market. Digest Finance, 2019, vol. 24,

iss. 1, pp. 3-12. 
product and earning partners' fees per each new customer. As a rule, they attract partners' customers, offering beneficial terms of loans and cash management.

Bancassurance is one of relatively new areas for mutually beneficial cooperation, i.e. cross-selling of banking and insurance products at banks' points of sales since these are banks that act as financial intermediaries in this scheme, possessing more reliable and sensitive data.

I analyzed bancassurance issues from perspectives of proceedings by O.D. Averchenko [1], E.S. Alekhina, I.N. Tret'yakova, A.E. Yablonskaya ${ }^{1}$, I.V. Babenko, A.I. Babenko², A.V. Zaitseva [2], G.F. Ruchkina [3], E.G. Sarsenova [4], T.Yu. Tarasova33, G.I. Shepelin [5], M.K. Yurik 4.

The fact that bancassurance parties are lured to cooperate is supported with statistics of the Central Bank of Russia acting as the megaregulator in the financial market (Fig. 1 and 2).

As showed in the Figures herein, insurance premiums in 2017 grew up by 8 percent mostly after a 15-percent increase in insurance compensation paid under insurance contracts secured by intermediaries, which amounted RUB 121,835.7 million in absolute values. Consequently, it captured an additional 4 percent of total insurance compensations in comparison with 2016, accounting for almost 75 percent.

\footnotetext{
${ }^{1}$ Alekhina E.S., Tret'yakova I.N., Yablonskaya A.E. [Theoretical aspects and current development trends in bank insurance in Russia]. Finansy $i$ kredit = Finance and Credit, 2015, vol. 22, iss. 26, pp. 25-38. URL: https://cyberleninka.ru/article/n/teoreticheskie-aspekty-isovremennye-tendentsii-razvitiya-bankostrahovaniya-v-rossii (In Russ.)

${ }^{2}$ Babenko I.V., Babenko A.I. [Bancassurance as a financial category. Evaluation of the Russian bancassurance services market]. Finansy $i$ kredit $=$ Finance and Credit, 2016, vol. 22, iss. 4, pp. 11-25. URL: https://cyberleninka.ru/article/n/bankostrahovanie-kakfinansovaya-kategoriya-otsenka-rossiyskogo-rynka-bankostrahovyhuslug (In Russ.)

${ }^{3}$ Tarasova T.Yu. [Bancassurance as a method for financial intermediaries to cooperate]. Vestnik Khabarovskogo gosudarstvennogo universiteta ekonomiki i prava, 2016, no. 3, pp. 4-8. (In Russ.) URL: http://www.vestnik.ael.ru/Portals/13/hgaep_umm/2016_vestnik_n3/\%D1 \%82\%D0\%B0\%D1\%80\%D0\%B0\%D1\%81\%D0\%BE\%D0\%B2\%D0\%B0_ \%D1\%81\%D1\%82\%D0\%B0\%D1\%82\%D1\%8C\%D1\%8F

\%D0\%B2\%D0\%B5\%D1\%81\%D1\%82\%D0\%BD\%D0\%B8\%D0\%BA.pdf

${ }^{4}$ Yurik M.K., Petrov K.S. [Some theoretical and practical aspects of the bank insurance]. Finansy $i$ kredit = Finance and Credit, 2010, no. 24, pp. 66-72. URL: https://cyberleninka.ru/article/v/nekotoryeteoreticheskie-i-prakticheskie-aspekty-bankovskogo-strahovaniya (In Russ.)
}

Interestingly, while the remaining intermediary-based options to obtain insurance premiums shrank (intermediary services of individuals and legal entities, brokers and car sellers, which are statistically highlighted by the Central Bank of Russia), insurers saw their financial proceeds from credit institutions increase, going up by RUB 99,687.6 million, or 6\%, thus covering 41 percent of insurance premiums under intermediary contracts in 2017 year on year.

In pursuit of profits as the main goal of their activities, commercial banks earn respective fees from insurance companies. The composition and dynamics of fees, which insurance companies pay to their intermediaries, are given in Table 1.

Referring to Table 1, we note these are credit institutions that benefited most of all in comparison with other intermediaries cooperating with insurance companies. In addition to the most notable absolute increase in insurance compensations, which is about RUB 97 billion in 2017 due to the record high amount of insurance premiums banks remitted under contracts (Fig. 2), the fee rate is 25 percent of insurance premium, i.e. twice as high as a similar rate for insurance brokers (12 percent). What is more, it is noteworthy that these are payments to banks that demonstrate more or less upward trend of 2.6 percent against 2016 among all intermediary's fees, while payments to individuals dropped by 4.1 percent.

The business cooperation of banks and insurance companies not only improves the customer satisfaction level but also enables both of them to effectively use the banking infrastructure and distribution network by insurance companies in particular.

Analyzing the current situation and trends in the bancassurance market, I hypothesize that its actors strive to derive profit within a short period of time without triggering long-term consequences, thus causing various risks, which, I assume, depend on the following factors:

- type of insurance products;

- the bank's status of beneficiary/agent;

- legal basis for the relationships between the bank and insurance company (whether they are affiliated or not).

As this article focuses on risks associated with banking and bancassurance in particular, I sort them out 
chronologically (Fig. 3 presents the proposed typification of risks).

Delving into the substance of risks indicated in Fig. 3, let us refer to the following facts.

Banking is inseparable of loan repayment insurance. As banks see their loan portfolio and value of pledged property increasing, the capacity of the credit risk insurance market expands as well. Although some issues of credit product insurance are solved, there are still some pending matters concerning the elimination of risks associated with credit insurance.

On June 1, 2016, Instruction of the Central Bank of Russia of November 20, 2015 № 3854-Y, On the Minimum (Ordinary) Requirements to the Terms and Procedure for Certain Types of Voluntary Insurance, came into effect. As per paragraph 1 of the Instruction, when the insurer enters into an insurance contract (save for some exceptions), it should stipulate the refund of insurance premium to the insured party within 14 consecutive days from the signing date of the contract no matter when such insurance premium is paid. Thus, providing for the cooling-off period, law-makers intended to protect customers from insurance services banks sometimes force them to use [6]. In such circumstances, borrowers are hustled to decide. They sign a loan agreement, without scrutinizing its terms properly and actually having an opportunity to decline it beforehand.

Such a novelty may seemingly be positive for the financially literate borrowers who intend to get their money back, being obfuscated by loan managers. However, things work in a different way.

The interaction of banks and customers and respective credit product issues were studied by P.A. Grishin, A.A. Tsyganov [7], E.A. Rusetskaya [8], D.V. Bryzgalov, A.D. Yazykov, A.G. Semenyuk [9].

Counting on the subsequent refund of insurance premium, the borrower must consider provisions of paragraph 11, Article 7 of the Law, On Unsecured Lending. As per the Law, if the borrower refuses to insure his/her unsecured loan, the bank is empowered to increase the interest rate on such an unsecured loan, offering an alternative lending option or require the borrower to pay it ahead of schedule.

\footnotetext{
${ }^{5}$ Federal Law of December 21, 2013 № 353-Ф3, On Unsecured Lending.
}

This provision seem rather fair since the borrower's refusal from insurance makes the loan more risky for the bank. This is envisaged in paragraph 4.8 and paragraph 6.3.1 of the Regulation for Credit Institutions to Make Provisions for Losses from Loans, Credit or Equal Debts. As per the Regulation, if the borrower agrees to conclude the life/health insurance contract (insurance in case of disability, accident, disease of an individual) and provides a collateral, this may seriously influence in estimating the provision for possible loan losses $^{6}$.

Therefore, if the borrower cancels the insurance policy during the cooling-off period, the bank may substitute one source of income, i.e. fees from the insurance company for its insurance product sold, with another one, i.e. the additional charge on the interest rate on a loan to set off the increased risk exposure. However, in the first case, the bank will surely derive its income when summing up sales of the insurance company's products. In the second case, income is deferred and probabilistic by nature because the borrower's inability to pay is concerned.

Trying to mitigate the risk, commercial banks offer (seemingly) very beneficial terms of loans, including the insurance policy. Therefore, banks persuade customers to opt for such insurance-inclusive products in comparison with identical ones without insurance addons. However, if we make a closer look at the substance of both products and different banks' propositions, we reveal almost equal pricing. For example, applying to UniCreditBank for an unsecured loan, the borrower will pay 13.9 percent per annum if the insurance policy is included into the loan agreement, or 17.9 percent per annum if the insurance-free option is chosen ${ }^{7}$. The insurance rate of the first option will be 0.3 percent of the loan per each month of the loan agreement term, or 3.6 percent per annum. Thus, the gross rate on the insured loan equals 17.5 percent $(13.9 \%+3.6 \%)$.

The insurance policy protects the borrower for the entire period of the loan agreement within the amount of insurance coverage, which equals the amount of the unsecured loan. In the mean time, it hedges the bank

\footnotetext{
${ }^{6}$ Regulation of the Central Bank of Russia of June 28, 2017 № 590-П, The Procedure for Credit Institutions to Make Provisions for Possible Loan Losses, Loans and Identical Debts. URL: http://www.consultant.ru/document/cons_doc_LAW_220089 / (In Russ.)

${ }^{7}$ Unsecured loan requirements. URL: https://www.unicreditbank.ru/ru/personal/borrow/cashloans/conditions.html (In Russ.)
}

Please cite this article as: Yusupova 0.A. Analysis of Credit Institutions' Risks in the Bancassurance Market. Digest Finance, 2019, vol. 24, iss. 1, pp. 3-12. 
acting as the beneficiary against the insurance risk and brings an immediate income, which approximates 25 percent of the respective fees on average ( 0.9 percent in the analyzable case) (please refer to Table 1 for explanatory comments), because insurance premium is paid on a one-off basis when the loan is made available under the loan agreement.

The cooling-off clause permitted borrowers to have their insurance premiums refunded before the insurance contract comes into force. However, as a matter of fact, with due regard to timing and cost of new terms of an insurance-free loan, this makes such a refund unreasonable, improbable in terms of the bank's risk, thus anyway enabling the bank to derive income from a virtually risk-free product.

The borrowers is well aware of the insurance product cost since. As per paragraph 2, Article 7 of the Law, On Unsecured Lending, ${ }^{8}$, offering borrowers additional services for an extra fee, including the insurance of life and(or) health, banks receives the borrower's consent for insurance services, including the conclusions of other contracts, which the borrower is to sign with respect to the unsecured loan agreement.

In an unsecured loan application, the creditor indicates the value of a service it offers and allows the borrower to accept or reject the service, including through other contracts which the borrower is to conclude with respect to the unsecured loan agreement.

When an unsecured loan is concerned, the law does not require the borrower to have his/her life, health, employment necessarily insured. However, what really and essentially helps sell insurance product is that the would-be borrower has already reviewed what banks offer and got understanding of the effective interest rate on loans. However, the borrower may be barely cognizant with the insurance market, being unable to evaluate the appropriateness of insurance tariffs and accepts the bank's proposition.

Having analyzed the effective laws, I found that the risk of insurance rejection is not common for all credit products of banks since borrowers are not always allowed to choose whether they accept insurance services or not.

First of all, it concerns the mortgage insurance (Article 31 of Federal Law of July 16, 1998 № 102-Ф3, On Mortgage (Pledge of Property)). As per the Law, if the

\footnotetext{
${ }^{8}$ Federal Law of December 21, 2013 № 353-Ф3, On Unsecured Lending.
}

borrower cancels the insurance contract he/she is bound to conclude for mortgage, he/she must enter into a new insurance contract with the insurer in compliance with the bank's requirements.

I suggest analyzing bancassurance risks associated with mortgage.

As per the law, the pledged property insurance is meant to protect and preserve the property. As specified in paragraph 1, Article 31 of Federal Law of July 1, 1998 № 102-Ф3, On Mortgage, the mortgage insurance contract shall pursue interests of the mortgagee (beneficiary), i.e. a credit institution. The insurance clause protects the mortgagee's interests because it really needs to avoid the loss (destruction) and damage of the pledged property. The insurance risk of the pledged property loss (destruction) implies that it may be totally destroyed. The damage risk means it its partial loss or substantive modification. The parties to the mortgage contract may enlist insurance risks in line with distinctive features of the pledged property, its location. If these aspects are not specified, insurance is based on general risks (for example, the risk of loss or damage of property due to fire or explosion, natural calamities, technological disasters, unlawful actions of third parties).

Insurance redirects pecuniary losses from the mortgagor to the insurer, which undertakes to indemnify losses caused to the insured property (insurance payout) in case of an insurance event within the contractually stipulated amount (insurance coverage).

Undoubtedly, the effective laws associate terms of mortgage contracts with a certain insurer. They simply sets the scope of discretion which the party in charge of insurance should mind when entering respective contracts.

Whereas, as per general rules, the pledged property shall be insured so to cover its full value, or, if its value exceeds the mortgage liability, the value of the creditor's claim secured with the mortgage, the absolute value of the insurance policy will be quite substantial.

In the case of mortgage, the credit institution is not exposed to the risk that the borrower declines an insurance offer because it is compulsory. However, acting as the beneficiary with respect to an insurance product, the bank cannot derive income by selling it, thus having the loss of opportunity. 
As prescribed in the Resolution of the RF Government, On Instances of Permitted Agreements between Credit Institutions and Insurance Companies ${ }^{9}$, the bank is not allowed to act simultaneously as an agent and beneficiary under insurance contracts.

Under such circumstances, banks lawfully establish insurance affiliates (or, on the contrary, insurance companies found banks). Therefore, as a matter of fact, the single corporate organism offers customers to acquire the full package of financial services, including key banking and insurance products. VTB Insurance, RSHB Insurance, AlfaStrakhovanie Group, Absolute Insurance, UralSib Insurance Company, etc. are the best representation of the above configuration. Banks and insurance companies within such groups also deal with capitalization issues by reallocating funds within the group. Handling the substantial volume of long-term funds, insurers can place them for a short period time with a credit institution, say, as short-term investment, finance of export and import.

In this respect, the sales department of the bank needs to persuade the borrower to conclude the mortgage insurance contract with the affiliated insurance company. Trying to maintain the competition, the Resolution, On Instances of Permitted Agreements between Credit Institutions and Insurance Companies ${ }^{10}$, require credit institutions to accept insurance contracts with any company borrowers choose provided that the later is compliant with credit institutions' requirements.

As prescribed by the law, the bank must inform its borrowers of uniform requirements to insurance companies, terms of services, timelines for checking necessary data and documents of an insurance company. Avoiding the loss of income in case borrowers choose unaffiliated insurance company, credit institutions deliberately obstruct such an option by setting specific and particular requirements to third party insurers, which only the affiliated insurance company can meet, thus generating all financial flows from mortgage within the group.

This idea is confirmed by Irina Baranova, the head of the retail banking department a UralSib Bank. She says the accreditation of an insurance company implies the

\footnotetext{
${ }^{9}$ Resolution of the RF Government of April 30, 2009 № 386, On Instances of Permitted Agreements between Credit Institutions and Insurance Companies.

${ }^{10}$ Resolution of the RF Government of April 30, 2009 № 386, On Instances of Permitted Agreements between Credit Institutions and Insurance Companies.
}

verification of its financial reliability and ability to perform its obligation to customers. Whereas each banks sets its own criteria, banks offer a different number of insurance companies to choose ${ }^{11}$. According to Viktor Klimov, the head of the All Russia People's Front, For the Rights of Borrowers, first of all, banks try to promote services of those insurance companies which pertain to the same holding group ${ }^{12} 12$.

If the central Bank of Russia maintains the low inflation rate as targeted as part of the monetary policy and funding gets more affordable due to a drop of the key rate, the interest rate on loans may reduce, thus spurring a growth in all lending segments [10]. However, the low rate of economic growth, intensifying competition for good borrowers, shortage of capital to cover risk and relocation of some retail deposits to more lucrative sources of investment substantially influence the lending activity of banks and make them search for additional sources of intermediary fees.

According to forecasts of the RA Expert Rating Agency, in 2018 bank's portfolio of loans will presumably grow by 6 percent and slightly outperform a 4-percent level recorded in 2017. As analysts emphasize, striving to offset a drop in the margin of loans and its sluggish growth, banks will be actively augment their interestfree income, thus increasing the profitability of the sector up to 10.5 percent (against 8.3 percent in 2017) and pushing it one-third closer to the pre-crisis level of 15-18 percent.

Considering the analyzable bancassurance market, it is interesting to note that the lending market will still be driven by retail loans as was in 2017 due to the positive trends in real disposable income of the population. Whereas experts, first of all, expect the portfolio of unsecured loans of individuals to increase (10 percent against 6 percent in 2017), concurrently having high margin and risks, it is possible to forecast a sales growth in the credit insurance market. The mortgage portfolio is expected to grow by 16 percent as a result of the launch of the Agency for Housing Mortgage Lending (AO DOM.RF since March 2018), governmental program for subsidizing the interest rate for families with many children, reduction in the coefficient the

\footnotetext{
${ }^{11}$ Dovesok k kreditu: mozhno li otkazat'sya ot navyazyvaemoi strakhovki [Add-on to the loan. May the borrower decline the aggressive offering of insurance services?].

URL: https://www.rbc.ru/money/27/10/2017/59edefdf9a79472c786b031

${ }^{12}$ Ibid.
}

Please cite this article as: Yusupova 0.A. Analysis of Credit Institutions' Risks in the Bancassurance Market. Digest Finance, 2019, vol. 24, iss. 1, pp. 3-12. 
securitization influences the capital, thus stimulating banks' intentions in the bancassurance segment.

In addition to the above efforts made to mitigate the risk of lower income or its loss, banks actively refocus from personal insurance contracts to collective ones which are not subject to the cooling-off clause.

What distinguishes personal insurance contracts (respective risks are reviewed above) is that such contracts are concluded by individuals (the insured) and legal entities (insurers). The insured (borrower) acts as the beneficiary and receives the insurance compensation in case of an insurance event. The insurance compensation depends on individual characteristics of the customer (age, work, insurance track record, etc.).

Collective insurance contracts help banks mitigate the risk of additional income in retail lending. Collective insurance contracts are made between banks and insurance companies. The lending bank, which hedges itself against risks of the borrower's default, is the beneficiary in such a scheme. The borrower is supposed to join the existing collective insurance plan. Whereas it is the bank that acts as the insured under collective insurance contract, such contracts are impossible to reject, though the plan accession costs are borne by the borrower.

The Central Bank of Russia plans to apply the coolingoff clause to collective insurance contract as well. It just ponders over the appropriate legal construct for this novelty. This will trigger the credit risk of the banking sector, thus correspondingly editing terms of lending propositions in the market.

As seen in the bancassurance segment today, banks serves as distribution channels for almost all types of insurance products. Although retail loans are more often than not supplemented with property insurance, protection from financial risks, accidents and life insurance, non-credit insurance product account for the substantial share of products sold through banks.

Private customers often apply for the following noncredit insurance products:

- life insurance;

- credit card fraud protection insurance;

- personal insurance of the deposit holder;

- travel insurance [11-15].
The above products can be sold without being inseparably attached to the respective banking product, putting pressure on customers by modifying terms of a deal in case customers decline the insurance option, lowering the probability that such a deal will be approved, or restricting access to refinance and restructuring programs.

In such circumstances, the bank's risk of insufficient fees from intermediated sales mostly arise from the talent, professional level of its staff and capability to customize the proposition.

In the non-credit insurance segment, I should mention its subtypes, which do not substantively relate to risks associated with a loan, but virtually influencing its approval. Such insurance products make a loan more expensive for the borrower, while being almost impracticable in case of an insurance event. For example, emergency roadside service, call and assistance of a commissioner in case of a road accident, car repair assistance, jump-starting of a car, replacement of a flat tire, towing, legal assistance, etc.

Intermediated sales of the above services usually generate fees for small and medium-sized banks, which are not very much concerned with their reputation risk. Discussion boards on the Internet feature opinions of customers who became captive consumers of such services credit institutions compelled them to accept.

Serious reputation risks are an integral part of credit institutions' activities in bancassurance. Regardless of the business and legal design of bancassurance architecture (consolidated business or partnership), it is the bank that serves as a counter selling an insurance product. That is why the bank is perceived to be primarily responsible for the quality of the insurance product.

What happened with Allianz Insurance Company in 2014, which served the largest banks in the financial market (VTB 24, OTP Bank, Home Credit Bank), really damaged the reputation of those banks, notwithstanding performance guarantees. According to Tat'yana Nikitina, the head of the Insurance Company Rating, Allianz wound up its retail practice since it had been demonstrating negative results for several years13.

Facing such a situation, a financially literate customer cannot but raise a reasonable question. How could an insolvent insurance company be accredited by the

Please cite this article as: Yusupova 0.A. Analysis of Credit Institutions' Risks in the Bancassurance Market. Digest Finance, 2019, vol. 24, 
renowned banks, continuing to be as such for several years?

The Regulation of the RF Government, On Instances of Permitted Agreements between Credit Institutions and Insurance Companies, governs the accreditation procedure only in terms of the antitrust law, forbidding banks to set up artificial barriers so to better position the insurance companies they partner with (for example, stipulating the authorized capital, amount of insurance premium, insurance reserves, equity of the insured in assessing its financial viability as part of the accreditation requirements). Hence, banks could undertake preventative measures before and after the clause came into effect.

Banks are often biased when accrediting insurance company. Having reviewed websites of credit institutions, I pointed out the following requirements they may set for insurers seeking to get accredited by the bank:

1) versatile activities of the insurance company (the insurance portfolio does not focus on one or two types of insurance services);

2) more than three years of insurance practices;

3) effective licenses and credentials allowing the insurance company to offer certain insurance products;

4) permanent office (branch, local office, etc.);

5) high capitalization;

6) imited concentration of financial and credit risks in the insurance portfolio;

7) transparent composition of shareholders;

8) non-existent pending instructions/writs/notices restricting the insurance company's operations;

9) non-existent instances of license suspension within a certain period, which is usually taken to equal a year;

10) no bankruptcy proceedings in progress;

11) solvency corroborated with the analysis of financial indicators;
12) available reinsurance programs, including international reinsurers of the investment class;

13) no negative experience for the bank in dealing with the insurance company;

14) presentation of financial statements with the information the bank needs;

15) insurance contracts compliant with the bank's requirements.

Having analyzed the composition and content of the requirement, I concluded they are rather exhaustive and mostly provide for all necessary and sufficient conditions for the bank to choose a reliable partner.

However, the problem is that the ultimate selection criteria for insurance companies remain the exclusive knowledge of the bank. Neither regulatory document clearly indicates them, leaving them quite opaque for the insurance market actors.

Furthermore, cooperating with several insurance companies, the bank, on the one hand, diversifies its own risks, and assumes partners' risks, on the other hand.

The bank can be exposed to the reputation risk even within the same consolidated group. The insolvency of Rosgosstrakh Insurance Company, a company of Okritie Group, is an illustrative case.

In the Russian bancassurance segment, profound causes of banking risks analyzed herein are rooted in systemic operational issues of banks and insurance companies. The fact that they remain unregulated may ignite a financial disaster in the nearest future. If, vying for competitive advantages, insurance companies continue reducing tariffs and increasing the amount of banks' agency fees, which outperform a growth in the insurance market, this will inflict the massive bankruptcy of insurance companies, loss of people and corporate customers' confidence in financial institutions, detriment of the megaregulator's reputation. The non-transparent accreditation mechanism and total transition from collective contracts to agency-based relationships will fuel abuses that parties may commit pursuing easy gains. 


\section{Table 1}

Structure and dynamics of fees paid by insurance organizations to intermediaries, million RUB

\begin{tabular}{|c|c|c|c|c|c|c|}
\hline Item & 31.12 .2016 & Percentage & 31.12 .2017 & Percentage & Absolute change & $\begin{array}{l}\text { Growth rate, } \\
\%\end{array}$ \\
\hline Intermediary fees (credit institutions) & $77,366.1$ & 45 & $96,858.6$ & 47 & $19,492.5$ & 125 \\
\hline $\begin{array}{l}\text { Intermediary fees (individuals, including sole } \\
\text { proprietors) }\end{array}$ & $53,684.2$ & 31 & $55,210.9$ & 27 & $1,526.7$ & 103 \\
\hline Intermediary fees (other legal entities) & $17,609.8$ & 10 & $21,471.1$ & 11 & $3,861.3$ & 122 \\
\hline $\begin{array}{l}\text { Intermediary fees (entities trading in motor } \\
\text { vehicles) }\end{array}$ & 11,338 & 7 & 13,887 & 7 & 2,549 & 122 \\
\hline Intermediary fees (insurance brokers) & $3,086,3$ & 2 & $4,222,2$ & 2 & $1,135.9$ & 137 \\
\hline Total intermediary fees & $172,502.7$ & 100 & $204,280.6$ & 100 & $31,777.9$ & 118 \\
\hline
\end{tabular}

Source: Authoring based on the Central Bank of the Russian Federation data.

URL: https://www.cbr.ru/analytics/?Prtld=analytics_nfo (In Russ.)

\section{Figure 1}

Structure of insurance premiums by source, million RUB

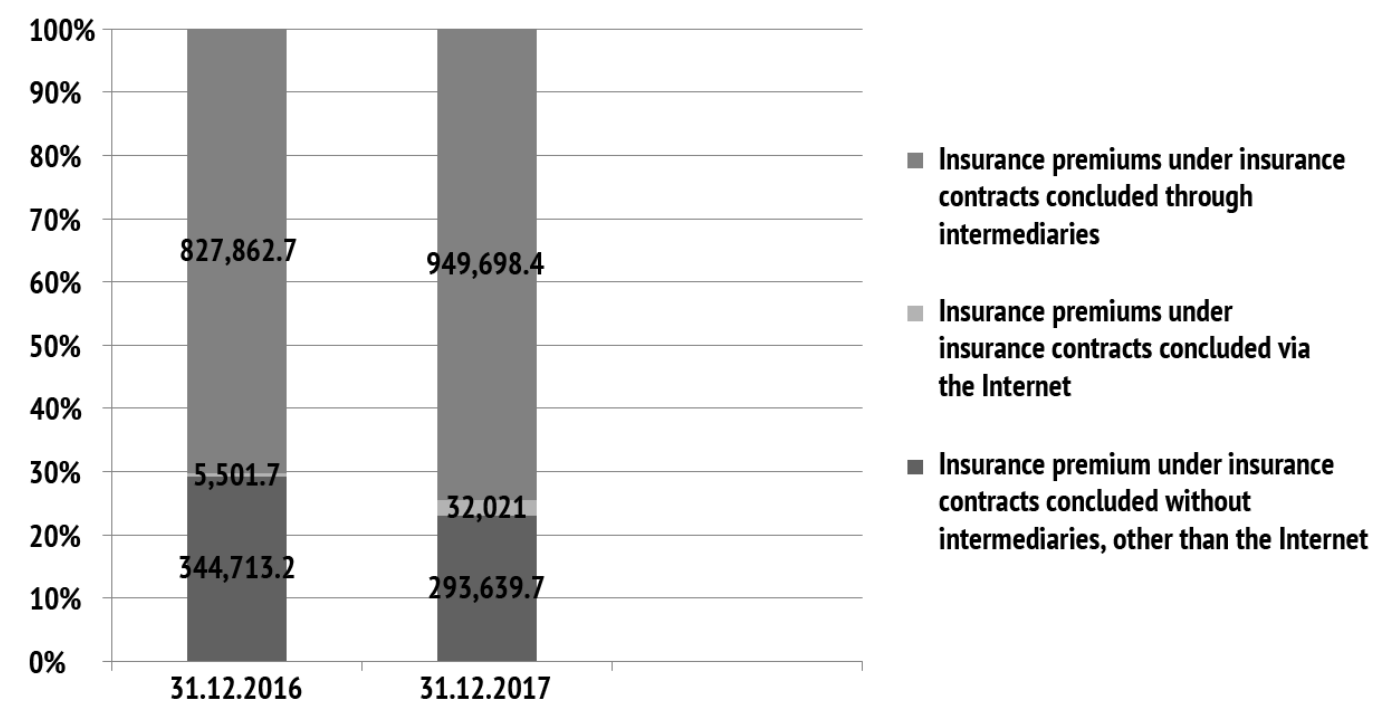

Source: Authoring based on the Central Bank of the Russian Federation data. URL: https://www.cbr.ru/analytics/?Prtld=analytics_nfo (In Russ.) iss. 1, pp. 3-12. 


\section{Figure 2}

Structure of insurance premiums under insurance contracts concluded through intermediaries, by type of intermediary, million RUB

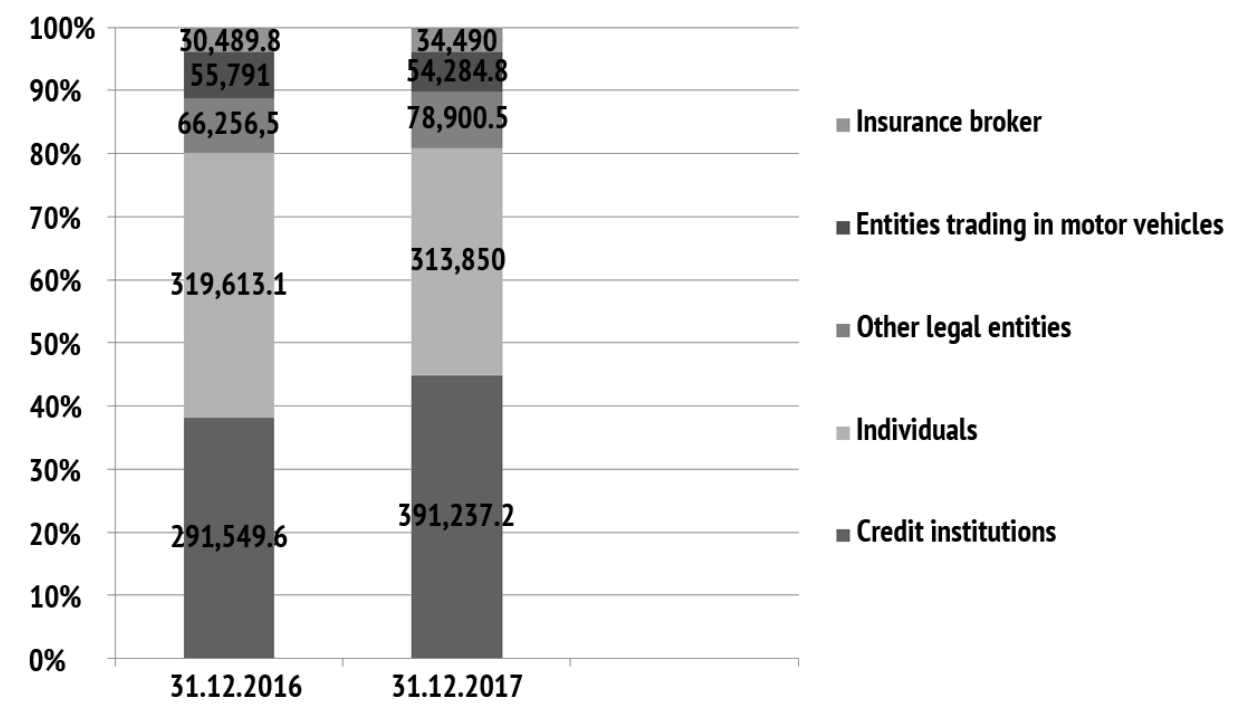

Source: Authoring based on the Central Bank of the Russian Federation data. URL: https://www.cbr.ru/analytics/?Prtld=analytics_nfo (In Russ.)

\section{Figure 3}

Classification of bank risks in the bancassurance market

\begin{tabular}{|c|c|c|c|c|c|}
\hline \multicolumn{6}{|c|}{ Bank risks in the bancassurance market } \\
\hline \multicolumn{3}{|l|}{ Credit } & \multicolumn{3}{|l|}{ Non-credit } \\
\hline \multirow{2}{*}{$\begin{array}{l}\text { Loss of fees due to the } \\
\text { borrower's cancellation } \\
\text { of insurance policy } \\
\text { during the cooling-off } \\
\text { period }\end{array}$} & \multirow[b]{2}{*}{$\begin{array}{l}\text { Insurance } \\
\text { compensation lost due } \\
\text { to bankruptcy or } \\
\text { contractual disputes } \\
\text { with the insurance } \\
\text { company }\end{array}$} & \multirow{2}{*}{$\begin{array}{l}\text { Loss of fees as the } \\
\text { borrower chooses the } \\
\text { insurance company on } \\
\text { his/her own discretion, } \\
\text { other than those } \\
\text { enlisted by the bank }\end{array}$} & \multicolumn{2}{|l|}{ Reputation risk } & \multirow{2}{*}{$\begin{array}{l}\text { Income lost as the } \\
\text { customer refuses to } \\
\text { acquire the services }\end{array}$} \\
\hline & & & $\begin{array}{l}\text { Due to the customer's } \\
\text { troubles with the } \\
\text { insurance company } \\
\text { recommended by the } \\
\text { bank }\end{array}$ & $\begin{array}{l}\text { Due to the sale of } \\
\text { unnencessary services } \\
\text { to the customers }\end{array}$ & \\
\hline
\end{tabular}

Source: Authoring

\section{References}

1. Averchenko O.D. [Conceptual approaches of the organization and functioning of the bancassurance modern forms]. Ekonomika i predprinimatel'stvo = Journal of Economy and Entrepreneurship, 2015, no. 11-2, pp. 868-871. (In Russ.)

2. Zaitseva A.V. [Insurance of bank risks: Legal construction, main areas and importance in bank activity]. Bankovskoe pravo = Banking Law, 2016, no. 5, pp. 62-65. (In Russ.)

3. Ruchkina G.F. [Obligations under credit contracts nominated in foreign currency and secured by mortgage: Some problems of restructuring]. Bankovskoe pravo = Banking Law, 2015, no. 1, pp. 7-11. (In Russ.)

4. Sarsenova E.G. [Bank assurance and problems of its development in Russia and foreign countries]. Baikal Research Journal, 2015, vol. 6, no. 3, pp. 13. (In Russ.) URL: https://doi.org/10.17150/2072-0904.2015.6(3).13 
5. Shepelin G.I., Krylova I.Yu. [Modern problems of bancassurance formation in Russia]. Ekonomika i sotsium, 2016, no. 1, pp. 1018-1023. (In Russ.) URL: https://iupr.ru/domains_data/files/zurnal_20/Shepelin \%20G.I.Osnovnoy\%20razdel\%20socialno-ekonomicheskie\%20aspekty\%20razvitiya\%20sovremennogo \%20gosudarstva.pdf

6. Yusupova O.A. [Investment lending in crisis]. Innovatsionnaya ekonomika i obshchestvo = Innovative Economy and Society, 2016, no. 2, pp. 81-88. (In Russ.)

7. Grishin P.A., Tsyganov A.A. [Analyzing the efficiency factors of a bank insurance group]. Finansy =Finance, 2007, no. 9, pp. 43-46. URL: https://www.lawmix.ru/bux/61065 (In Russ.)

8. Rusetskaya E.A. [Insurance development as a tool to increase economic security efficiency in Russia]. Regional'naya ekonomika: teoriya i praktika = Regional Economics: Theory and Practice, 2010, no. 6, pp. 40-48. URL: https://cyberleninka.ru/article/n/razvitie-strahovaniya-kak-instrumenta-povysheniyaeffektivnoy-sistemy-ekonomicheskoy-bezopasnosti-strany (In Russ.)

9. Tsyganov A.A., Bryzgalov D.V., Yazykov A.D., Semenyuk A.G. [Applying insurance mechanisms to increase the availability of mortgage loans for the Russian population]. Finansovaya analitika: problemy $i$ resheniya $=$ Financial Analytics: Science and Experience, 2015, vol. 8, iss. 1, pp. 11-20.

URL: https://cyberleninka.ru/article/n/primenenie-mehanizmov-strahovaniya-dlya-povysheniya-dostupnostiipotechnyh-kreditov-dlya-naseleniya-rossii (In Russ.)

10. Yusupova O.A. [Development of remote banking and its place in the banking competitive environment]. Finansovaya analitika: problemy i resheniya = Financial Analytics: Science and Experience, 2016, vol. 9, iss. 33, pp. 37-51. URL: https://cyberleninka.ru/article/n/razvitie-i-mesto-distantsionnogo-bankovskogoobsluzhivaniya-v-bankovskoy-konkurentnoy-srede (In Russ.)

11. Ekimov A.V. [Bancassurance development in Russia: Problems and prospects]. Vestnik Samarskogo gosudarstvennogo ekonomicheskogo universiteta = Vestnik of Samara State University of Economics, 2016, no. 2, pp. 90-96. URL: http://vestnik.sseu.ru/index.php?cnt=1\&idv=279 (In Russ.)

12. Nechaev A.I. [Interaction between banking and insurance companies in Russia: Development prospects]. Teoriya i praktika obshchestvennogo razvitiya = Theory and Practice of Social Development, 2018, no. 2, pp. 1-6. URL: https://cyberleninka.ru/article/n/razvitie-vzaimodeystviya-bankovskih-uchrezhdeniy-i-strahovyhkompaniy-v-rossii (In Russ.)

13. Podoprigora I.V., Mendus' R.R. [The development of bank insurance]. Vektor ekonomiki = Vector of Economy, 2017, no. 2, p. 14. (In Russ.)

14. Fomina K.S., Rogozhkina N.S. [Bancassurance and prospects for its development]. Integratsiya nauk= Integration of Sciences, 2017, no. 4, pp. 40-42. (In Russ.)

15. Kheinonen V.A. [The Study on tendencies of bank assurance development in Russia]. Korporativnaya ekonomika, 2018, no. 2, pp. 34-44. (In Russ.)

\section{Conflict-of-interest notification}

I, the author of this article, bindingly and explicitly declare of the partial and total lack of actual or potential conflict of interest with any other third party whatsoever, which may arise as a result of the publication of this article. This statement relates to the study, data collection and interpretation, writing and preparation of the article, and the decision to submit the manuscript for publication. 